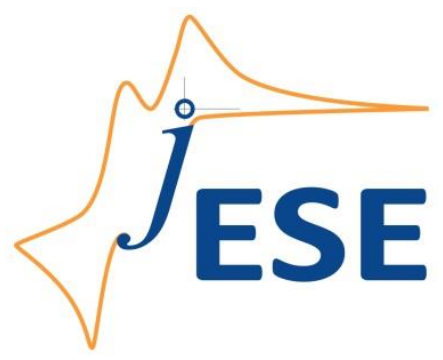

Open Access : : ISSN 1847-9286

www.jESE-online.org

Original scientific paper

\title{
Methanol oxidation at platinized copper particles prepared by galvanic replacement
}

Ioanna Mintsouli*, Jenia Georgieva**, Athanasios Papaderakis*, Stephan Armyanov**, Eugenia Valova**, Volodymyr Khomenko***, Stella Balomenou****, Dimitrios Tsiplakides******, Sotiris Sotiropoulos* $*$

*Department of Chemistry, Aristotle University of Thessaloniki, Thessaloniki 54124, Greece

**Rostislaw Kaischew Institute of Physical Chemistry, Bulgarian Academy of Sciences, Sofia 1113,

Bulgaria

***Kiev National University of Technologies and Design, Department for Electrochemical Power Engineering \& Chemistry, Kiev 01011, Ukraine

****Chemical Process \& Energy Resources Institute, Centre for Research and Technology Hellas, 570 01, Thermi, Thessaloniki, Greece

${ }^{\square}$ Corresponding Author: eczss@chem.auth.gr; Tel.: +30-2310-997-742; Fax: +30-2310-997-709

Received: October 14, 2015; Accepted November 23, 2015

\begin{abstract}
Bimetallic Pt-Cu particles have been prepared by galvanic replacement of Cu precursor nanoparticles, upon the treatment of the latter with a chloro-platinate acidic solution. The resulting particles, typically a few tens of $\mathrm{nm}$ large, were supported on high surface area carbon (Vulcan ${ }^{\circledR}$ XC-72R, Cabot) and tested as electrodes. Surface electrochemistry in deaerated acid solutions was similar to that of pure Pt, indicating the existence of a $P t$ shell (hence the particles are denoted as Pt(Cu)). Pt(Cu)/C supported catalysts exhibit superior carbon monoxide and methanol oxidation activity with respect to their $P t / C$ analogues when compared on a per electroactive surface area basis, due to the modification of Pt activity by $\mathrm{Cu}$ residing in the particle core. However, as a result of large particle size and agglomeration phenomena, $\mathrm{Pt}(\mathrm{Cu}) / \mathrm{C}$ are still inferior to $\mathrm{Pt} / \mathrm{C}$ when compared on a mass specific activity basis.
\end{abstract}

\section{Keywords}

Transmetalation; Electrocatalysts; Platinum

\section{Introduction}

The need for reducing the cost and at the same time maintaining or improving the performance of catalysts used in fuel cells and electrolyzers has led to intensive research into non-precious me- 
tal alternatives or multi-metallic noble-metal-based systems. All common preparation methods for the latter involve a reduction step, either using a reducing agent in solution phase or in a reducing atmosphere (e.g. hydrogen) at elevated temperatures [1-5]. A high surface area support (usually carbon) is either present in the catalyst synthesis mixture or added during a subsequent step.

Since the appearance of the first papers on the subject [6-12], galvanic replacement has been established during the last decade as an alternative method for preparing multi-metallic noblemetal-based electrode materials. The principle of the method lies on the fact that when a nonnoble metal (e.g. $\mathrm{Pb}, \mathrm{Cu}, \mathrm{Fe}, \mathrm{Co}, \mathrm{Ni}, \mathrm{Mo}, \mathrm{Bi}$ ) is immersed in a solution containing ions of a noble metal (e.g. Pt, $\mathrm{Au}, \mathrm{Pd}, \mathrm{Ir}, \mathrm{Ru}$ ) then, due to a difference in standard potentials, the latter is deposited in metallic form replacing layers of the former (which is oxidized/released in ionic form in the solution). An example of the process for $\mathrm{Cu}$ and $\mathrm{Pt}$, resulting in a Pt-rich shell and a $\mathrm{Cu}$ containing core (denoted as $\mathrm{Pt}(\mathrm{Cu})$ ), is given by reaction (1) below:

$$
2 \mathrm{Cu}+\mathrm{PtCl}_{6}{ }^{2-} \rightarrow \mathrm{Pt}+6 \mathrm{Cl}^{-}+2 \mathrm{Cu}^{2+}
$$

Among advantages of the technique one can mention its room temperature conditions, the use of dilute solutions of the precious metal, as well as the potential formation of a noble-metal-rich shell / bimetallic-core structure. The latter can reduce the amount of the precious metal in the catalyst and also lead to beneficial electronic effects of the second metal on its catalytic activity. There have been three main research groups in the area. Adzic and co-workers have put emphasis on the replacement of $\mathrm{CU}$ UPD monolayers by precious metals and the catalysis of oxygen reduction (see for example [8-10,13-19]); Kokkinidis, Sotiropoulos and co-workers have used the replacement of surface layers of transition metal deposits by $\mathrm{Pt}$, mostly for methanol oxidation catalysis and with a recent emphasis on catalyst preparation on carbon and semiconductor oxide high surface area supports [11-12,20-33]; finally, Podlovchenko and co-workers have focused on the replacement of $\mathrm{Cu}$ or Mo layers by $\mathrm{Pt}$ or $\mathrm{Pd}$ and their use as methanol and formic acid oxidation catalysts [34-39].

Methanol oxidation in acid is the fuel reaction in direct methanol fuel cells (see for example [40-41]) which are envisaged as candidates for portable/micro-fuel cells. To improve tolerance towards CO intermediate poisoning, multi-metallic systems based on Pt have long been explored. Foreign metals adsorbed as ad-atoms or alloyed with Pt have been extensively studied (see for example [42-46]). We have tested the catalytic activity of $\mathrm{Pt}(\mathrm{Pb})$ [20] and $\mathrm{Pt}(\mathrm{Cu}), \mathrm{Pt}(\mathrm{Ni}), \mathrm{Pt}(\mathrm{Co})$ [26] core-shell catalytic layers on glassy carbon electrodes and have found a pronounced activity and stability of the $\mathrm{Pt}(\mathrm{Cu})$ formulations towards methanol oxidation. A rather limited number of papers of $\mathrm{Pt}(\mathrm{Cu})$ particles prepared by chemical methods on $\mathrm{C}$ particle supports can be found in the literature [29-33,47-52], which include those by our group [29-33]. In all but a few of these works $[48,49,52]$ galvanic replacement occurred after the $\mathrm{Cu}$ precursor was cast on the $\mathrm{C}$ support or in the presence of the latter. As discussed in [29], the presence of the conducting C particles provides an alternative location for Pt deposition (to that of the surface of $\mathrm{Cu}$ ): electrons released from $\mathrm{Cu}$ dissolving in the solution can travel through $\mathrm{C}$ to nearby locations whereby $\mathrm{Pt}$ ions can be reduced and deposited as metallic $\mathrm{Pt}$. In that case the catalyst comprises of a mixture of $\mathrm{Pt}(\mathrm{Cu})$ and pure $\mathrm{Pt}$ particles, moderating the beneficial effect of $\mathrm{Cu}$ on Pt catalytic activity. However, if the $\mathrm{Pt}(\mathrm{Cu})$ particles were first to be synthesized and then mixed with/ancored on the $C$ particles one would ensure the bimetallic character of the catalyst.

The aim of this work has been to prepare $\mathrm{Pt}(\mathrm{Cu})$ bimetallic particles by the galvanic replacement technique and then use them as supported catalysts for methanol oxidation. Specific 
objectives have been: $i$. The preparation of $\mathrm{Cu}$ nanoparticles and their conversion into platinized bimetallic particles; ii. The microscopic, spectroscopic and crysrallographic characterization of the $\mathrm{Pt}(\mathrm{Cu})$ and $\mathrm{Pt}(\mathrm{Cu}) / \mathrm{C}$ materials; iii. The electrochemical characterization of the deposits by means of Pt surface electrochemistry in acid, $\mathrm{CO}$ oxidation and methanol oxidation.

\section{Experimental}

\section{a. Preparation of $\mathrm{Cu}$ and Pt(Cu) nanoparticles and Pt(Cu)/C modified electrodes}

The $\mathrm{Cu}$ powder was prepared by reduction in a hydrogen-containing recirculate gas stream. The required amount of $\mathrm{Cu}\left(\mathrm{NO}_{3}\right)_{2} \cdot 3 \mathrm{H}_{2} \mathrm{O}$ was dissolved in a 1:1 water-ethanol mixture and heated at $80^{\circ} \mathrm{C}$ for $1 \mathrm{~h} 30 \mathrm{~min}$ under stirring until complete solvent evaporation. The resulting solid was crushed in a mortar and then placed in a crucible and thermally treated for 60 min at $300^{\circ} \mathrm{C}$ in an $\mathrm{Ar}$ atmosphere for $\mathrm{CuO}$ formation. In our experiments metallic copper powder was obtained by the reaction of $\mathrm{CuO}$ at $250{ }^{\circ} \mathrm{C}$ under a $8 \% \mathrm{H}_{2} / 92 \%$ Ar mixture (gas flow $20 \mathrm{~cm}^{3} / \mathrm{min}$ ) for $60 \mathrm{~min}$. Finally, the powder was left to cool to room temperature under Ar.

In a typical process, $0.05 \mathrm{~g}$ of freshly prepared $\mathrm{Cu}$ particles were added in $25 \mathrm{ml}$ of a $5 \times 10^{-3} \mathrm{M}$ $\mathrm{K}_{2} \mathrm{PtCl}_{6}+0.1 \mathrm{M} \mathrm{HCl}$ dearated solution and were sonicated for $45 \mathrm{~min}$ in an ultrasound bath so that spontaneous partial replacement of $\mathrm{Cu}$ by Pt could take place:

$$
2 \mathrm{Cu}(\mathrm{Cu})+\mathrm{PtCl}_{6}^{2-} \rightarrow \mathrm{Pt}(\mathrm{Cu})+2 \mathrm{Cu}^{2+}+6 \mathrm{Cl}^{-}
$$

((Cu) denotes copper in the bulk/core of the particles).

Finally, the suspension is filtered to obtain ca $0.022 \mathrm{~g}$ of a black powder product $(\mathrm{Pt}(\mathrm{Cu}))$. Note that the filtrate has turned light blue (indicative of the release of $\mathrm{Cu}$ ions according to (2)) from the originally light yellow colour of the suspension (due to $\mathrm{K}_{2} \mathrm{PtCl}_{6}$ ). $0.0173 \mathrm{~g}$ of the $\mathrm{Pt}(\mathrm{Cu}$ ) powder were mixed with $0.0692 \mathrm{~g}$ of carbon powder (Vulcan ${ }^{\circledR}$ XC-72R Cabot) so that the mixture was $20 \%$ $\mathrm{w} / \mathrm{w}$ in the catalyst. The $\mathrm{Pt}(\mathrm{Cu}) / \mathrm{C}$ mixture was dispersed in $1 \mathrm{ml}$ ethanol and was ultrasonicated for $5 \mathrm{~min}$ and then left to dry.

For the electrochemical testing of the catalyst, $3 \mathrm{mg}$ of the thus prepared $\mathrm{Pt}(\mathrm{Cu}) / \mathrm{C}$ material (or of commercial $20 \% \mathrm{w} / \mathrm{w} \mathrm{Pt} / \mathrm{C}$ catalyst, ETEK) were suspended in $0.5 \mathrm{ml}$ methanol together with drops of a Nafion ${ }^{\circledR}$ (protonic form) $5 \% \mathrm{w} / \mathrm{w}$ solution in a mixture of low aliphatic alcohols and $45 \%$ water (Aldrich), amounting to $2.5 \mathrm{mg}$ of Nafion ${ }^{\circledR}$ polymer. The as prepared suspension was homogenized in an ultrasonic bath and a given quantity of the slurry (containing the desired catalyst + support weight in the 0.8-1 mg range) was placed in a drop-wise manner on a flat glassy carbon electrode (GC, BAS Inc.) over a total area of $0.385 \mathrm{~cm}^{2}$ and left to dry. The resulting Pt loading in the $\mathrm{Pt}(\mathrm{Cu}) / \mathrm{C}$ electrode whose results are presented here (based on the EDS analysis of the catalyst, see also below) was $0.20 \mathrm{mg}_{\mathrm{Pt}} \mathrm{cm}^{-2}$; that of the $20 \% \mathrm{w} / \mathrm{w} \mathrm{Pt} / \mathrm{C}$ commercial catalyst was $0.43 \mathrm{mg}_{\mathrm{Pt}} \mathrm{cm}^{-2}$.

\section{b. Microscopic, spectroscopic and crystallographic characterisation of materials}

Scanning Electron Microscopy (SEM) was carried out using a JEOL JSM-5510 microscope and elemental analysis of the coatings was performed by the accompanying EDS (EDAX) system. The morphology of the catalysts was investigated with high resolution transmission electron microscopy (TEM) using a JEOL JEM 2010 microscope coupled with Oxford INCA X-ray EDS. X-Ray Diffraction (XRD) deposit characterisation was performed with the help of a Rigakou Miniflex diffractometer. 


\section{c. Electrochemical experiments}

Voltammetry was carried out with an Autolab 30 (EcoChimie) system in a three-electrode cell. A saturated calomel electrode (SCE) was used as the reference electrode and a Pt foil as the counter electrode.

The catalytic electrode was first scanned in a deaerated $0.1 \mathrm{M} \mathrm{HClO}_{4}$ solution between the hydrogen and oxygen evolution potential limits at $500 \mathrm{mV} \mathrm{s}^{-1}$ until a steady state voltammetric picture was recorded (typically after 20-30 cycles, whereby anodic currents due to uncovered $\mathrm{Cu}$ dissolution vanished). Next, the electrode was scanned again in a fresh deaerated $0.1 \mathrm{M} \mathrm{HClO}_{4}$ solution at $10 \mathrm{mV} \mathrm{s}^{-1}$, for a steady state voltammogram (typical of Pt) to be attained (typically after 2-3 cycles). Following that, the solution was saturated with pure CO gas ( $>99.99 \%$ purity; Air Liquide) and the electrode was polarized at $+0.10 \mathrm{~V}$ vs. SCE for $5 \mathrm{~min}$ (for CO adsorption to take place) and then scanned to more positive potentials at $50 \mathrm{mV} \mathrm{s}^{-1}$ (for CO oxidative removal). Finally, the electrode was scanned in a $0.5 \mathrm{MeOH}+0.1 \mathrm{M} \mathrm{HClO}_{4}$ solution at $5 \mathrm{mV} \mathrm{s}^{-1}$ to study the methanol oxidation reaction.

\section{d. Chemicals}

$\mathrm{Cu}\left(\mathrm{NO}_{3}\right)_{2} \cdot 3 \mathrm{H}_{2} \mathrm{O}$ from Sigma-Aldrich (ACS reagent) was used in the precursor solutions for $\mathrm{Cu}$ particle preparation. $\mathrm{H}_{2} \mathrm{PtCl}_{6}$ hexahydrate from Sigma-Aldrich (ACS reagent, $\geq 37.50 \%$ as $\mathrm{Pt}$ ) was employed for the Pt exchange solution. $\mathrm{MeOH}$ was from Riedel (Chromasolv ${ }^{\circledR}$, for HPLC, gradient grade, $\geq 99.9 \%$ ). $\mathrm{HClO}_{4}$ from Riedel, (puriss p.a., ACS reagent, $\geq 70 \%$ ) was added both in the galvanic replacement solution and as the supporting electrolyte in $\mathrm{MeOH}$ oxidation experiments.

\section{Results and discussion}

a. Microscopic, spectroscopic and crystallographic characterisation of $\mathrm{Cu}, \mathrm{Pt}(\mathrm{Cu})$ and $\mathrm{Pt}(\mathrm{Cu}) / \mathrm{C}$ particles

Figure 1 shows the XRD diffractogram of the freshly prepared $\mathrm{Cu}$ nanoparticles. It can be seen that these are made of metallic $\mathrm{Cu}$, as expected for a material annealed in a reductive atmosphere (see Experimental). The average crystallite size could be estimated as $43 \mathrm{~nm}$, using Scherrer's formula for the sharp $2 \theta_{\mathrm{Cu}(111)}=43.4501$ degrees peak. It should be noted that, despite prolonged ultrasonic treatment of $\mathrm{Cu}$ particle suspensions in ethanol, these were heavily aggregated and no individual particles or even nano-sized aggregates could be identified by TEM microscopy.

Figure 2 is a SEM micrograph of the filter cake of as prepared $\mathrm{Pt}(\mathrm{Cu})$ material, prepared by the partial galvanic replacement of $\mathrm{Cu}$ by $\mathrm{Pt}$. The as prepared material is particulate and consists of aggregates smaller than $1 \mu \mathrm{m}$. EDS analysis gave a $\mathrm{Pt} \div \mathrm{Cu} \div \mathrm{O}$ atomic ratio of $22 \div 70 \div 8$, indicating a $\mathrm{Cu}$-rich material (with some $\mathrm{Cu}$ oxides also formed during galvanic replacement or/and prolonged exposure to atmosphere).

Figure 3 presents the XRD difractogram of the $\mathrm{Pt}(\mathrm{Cu})$ catalyst and the wide peaks correspond to small crystallites, estimated to have an average size of ca $4 \mathrm{~nm}$, using Scherrer's formula. The shrinkage of crystallites from 43 to $4 \mathrm{~nm}$ as one passes from $\mathrm{Cu}$ to $\mathrm{Pt}(\mathrm{Cu})$ is in line with $\mathrm{Cu}$ dissolving as Pt deposits on its surface according to the galvanic replacement mechanism. The shift of the Pt peaks to lower $\theta$ values is indicative of alloy formation between Pt and a metal with a smaller lattice constant such as Cu. Using Vegard's law, the atomic composition of the alloy is estimated as $\mathrm{Pt} \div \mathrm{Cu}=73 \div 27$. Comparing this composition with that of the EDS results $(22 \div 70)$ it follows that a large part of Cu remains non-alloyed, most likely as very small pockets of amorphous material within the $\mathrm{Pt}(\mathrm{Cu})$ particles; the degree of alloying can thus estimated not to exceed $37 \%$ and expected to be restricted to the outer part of the particles. 


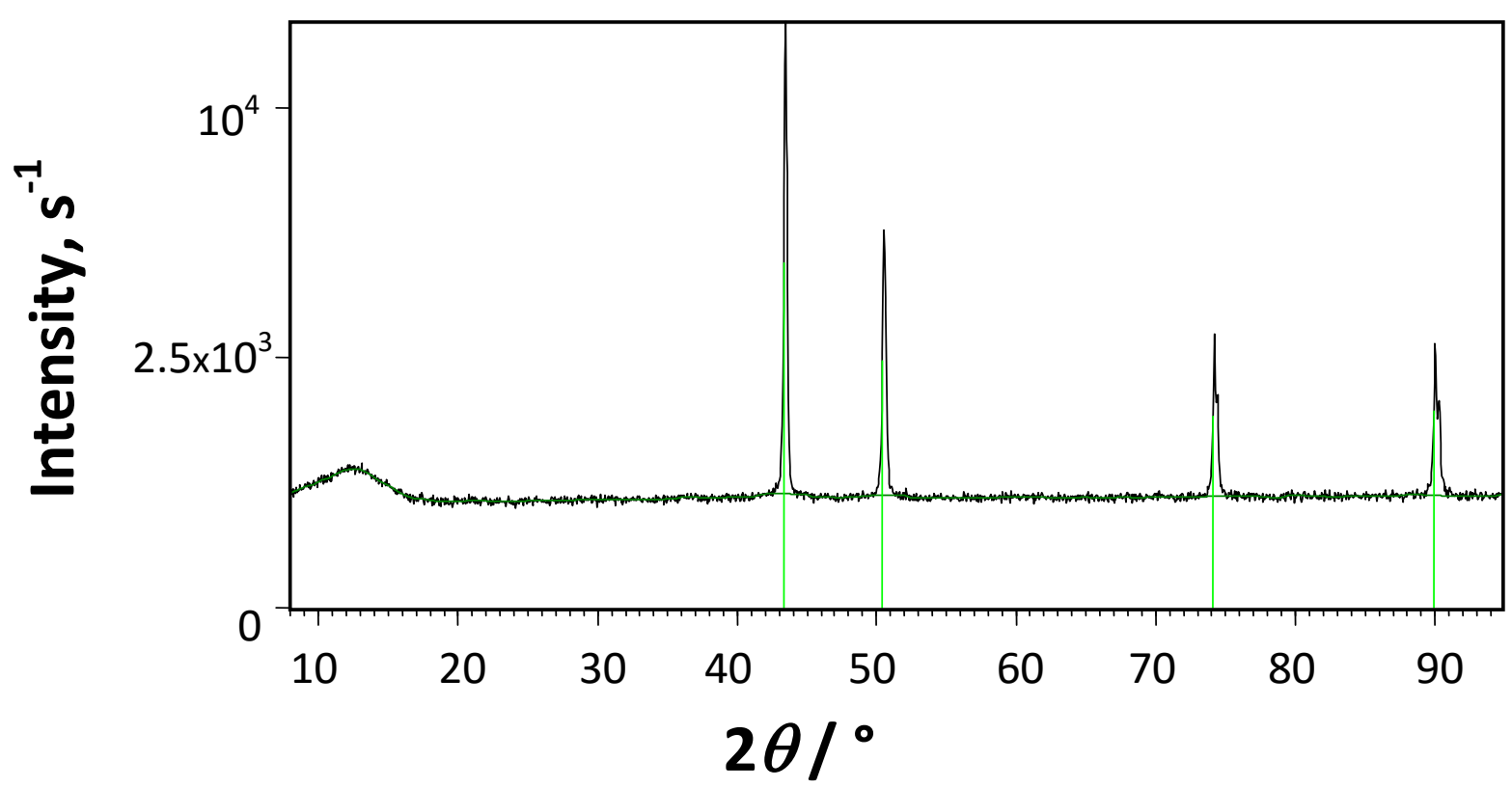

Figure 1. XRD diffractogram ( of Cu particles prepared by hydrothermal treatment of $\mathrm{Cu}\left(\mathrm{CH}_{3} \mathrm{COO}\right)_{2}$ followed by high temperature reduction in a hydrogen atmosphere (see Experimental)

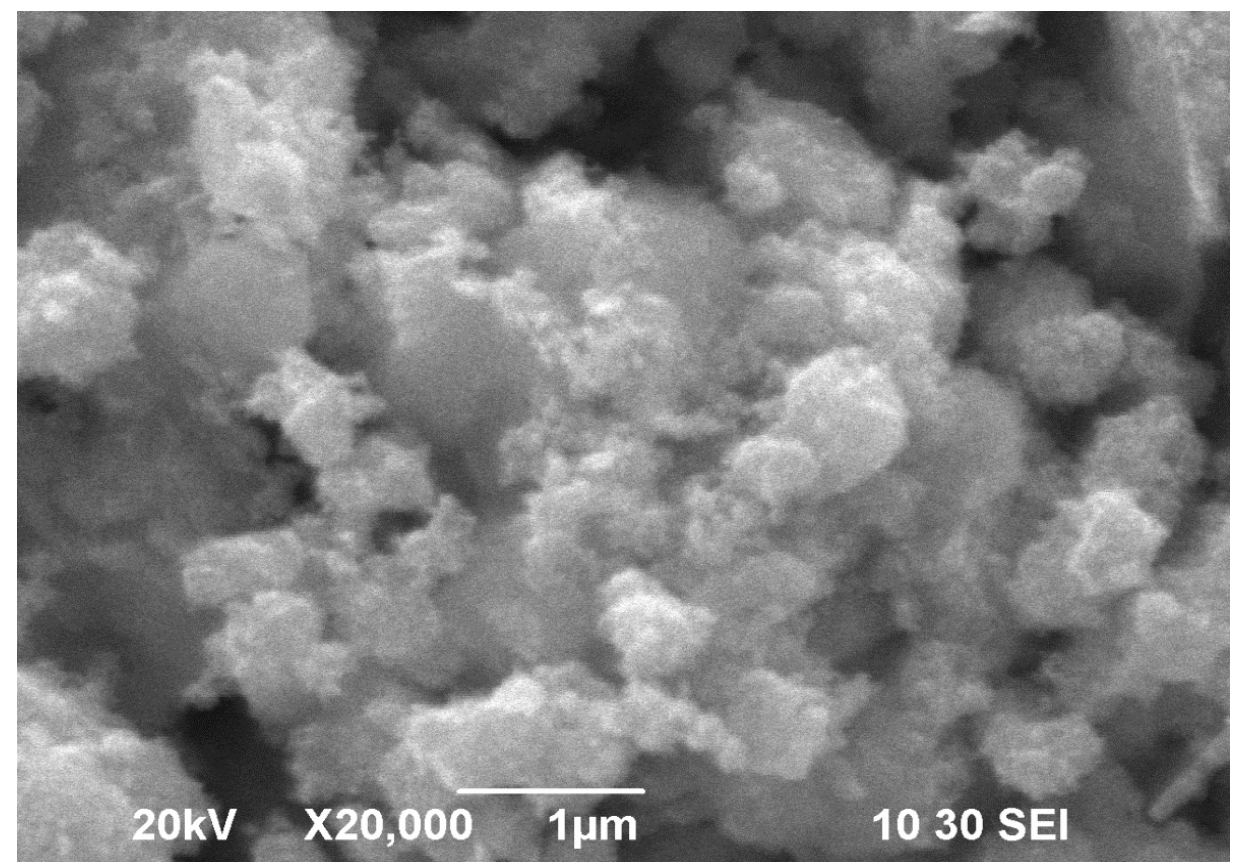

Figure 2. SEM micrographs of the filter cake of Pt(Cu) particles, prepared by hydrothermal treatment of $\mathrm{Cu}\left(\mathrm{CH}_{3} \mathrm{COO}\right)_{2}$ followed by high temperature reduction in a hydrogen atmosphere (see Experimental)

Figure 4 shows TEM micrographs of a $\mathrm{Pt}(\mathrm{Cu})$ large aggregate $(\mathrm{A})$ and of detached smaller aggregates of the material $(\mathrm{B})$, following dispersion of the $\mathrm{Pt}(\mathrm{Cu})$ filtrate of Figure 2 in ethanol (with magnetic stirring). The smaller particles are spherical in shape with dimensions in the 20-30 $\mathrm{nm}$ range and they seem to consist of even smaller particles; the atomic composition of each individual particle is found by EDS to be $\mathrm{Pt} \div \mathrm{Cu}=30 \div 70$, in line with what was found for the material as a whole (see above). 


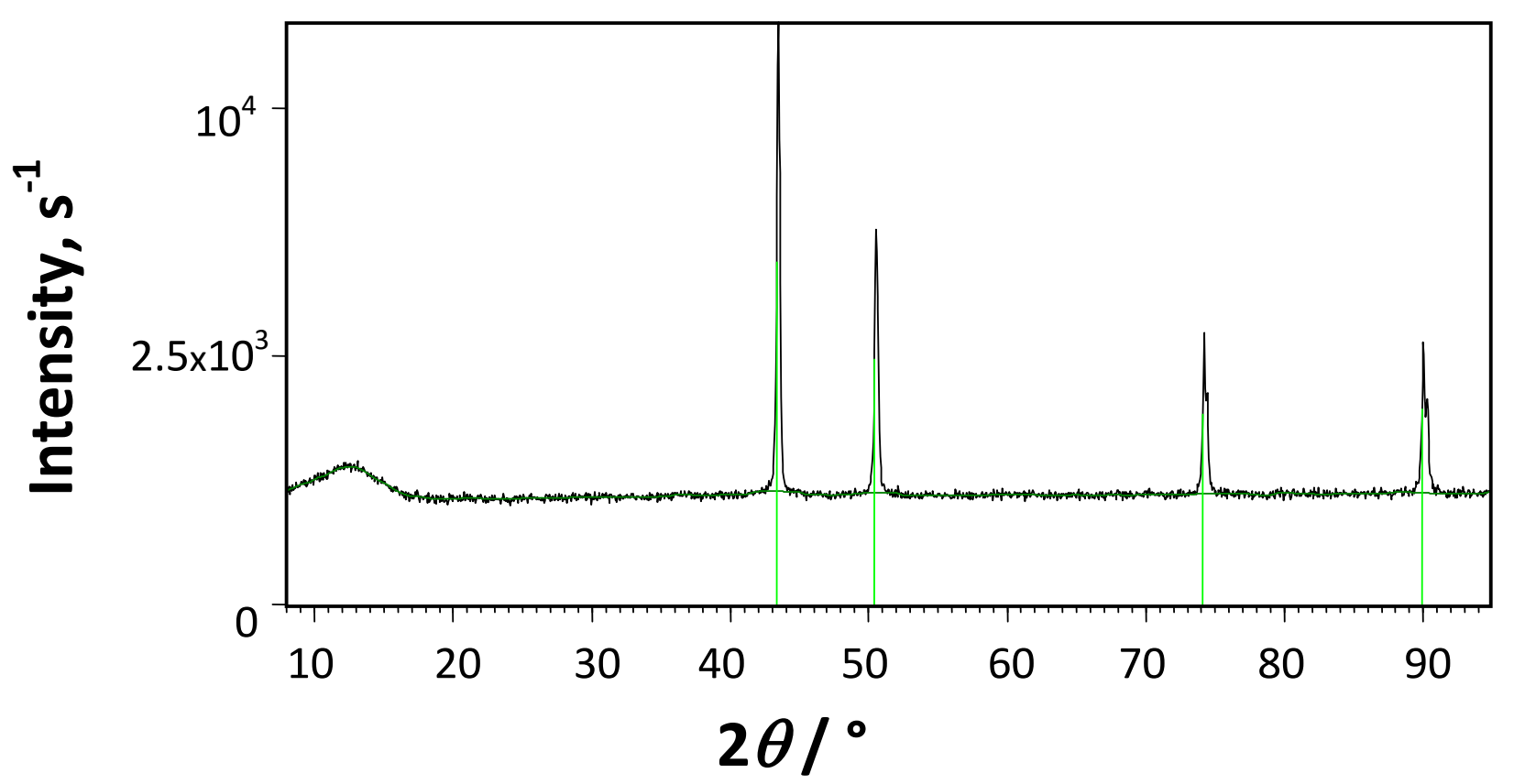

Figure 3. XRD diffractogram of Pt(CU) particles prepared by galvanic replacement of Cu particles' surface upon immersion of the latter in a solution containing Pt in ionic form (see Experimental)

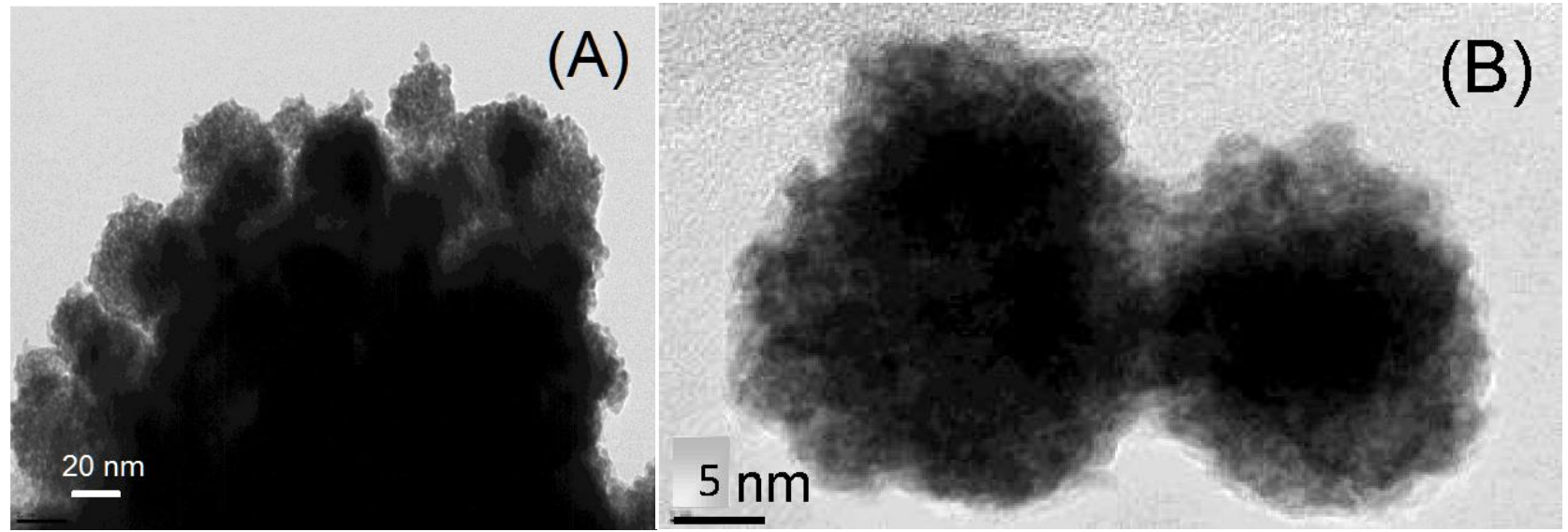

Figure 4. TEM micrographs of Pt(Cu) particles prepared by galvanic replacement of $\mathrm{Cu}$ particles' surface upon immersion of the latter in a solution containing Pt in ionic form (see Experimental); (A) Micrograph of a large aggregate, (B) Micrograph of individual particles

Figure 5 shows TEM micrographs of the $\mathrm{Pt}(\mathrm{Cu})$ particles supported on /mixed with $\mathrm{C}$ particles by means of ultrasonic treatment in ethanol. In Figure $5(A)$ the spherical carbon support particles are seen, having a fairly even size distribution of ca. $30 \mathrm{~nm}$. Figure $5(B)$ reveals the scatter of small (less than $20 \mathrm{~nm}$ in diameter) $\mathrm{Pt}(\mathrm{Cu})$ particles (seen as dark spots) in the $\mathrm{Pt}(\mathrm{Cu}) / \mathrm{C}$ system, whereas Figure $5(C)$ depicts in more detail an individual such particle. The observed morphology of individual particles is in line with the expected deposition of Pt clusters on top of a Cu rich core. Figure 5(D) shows the Pt nanoparticles of a commercial Pt/C catalyst made of very small nanoparticles (2-3 $\mathrm{nm}$ ) with limited aggregation phenomena. 

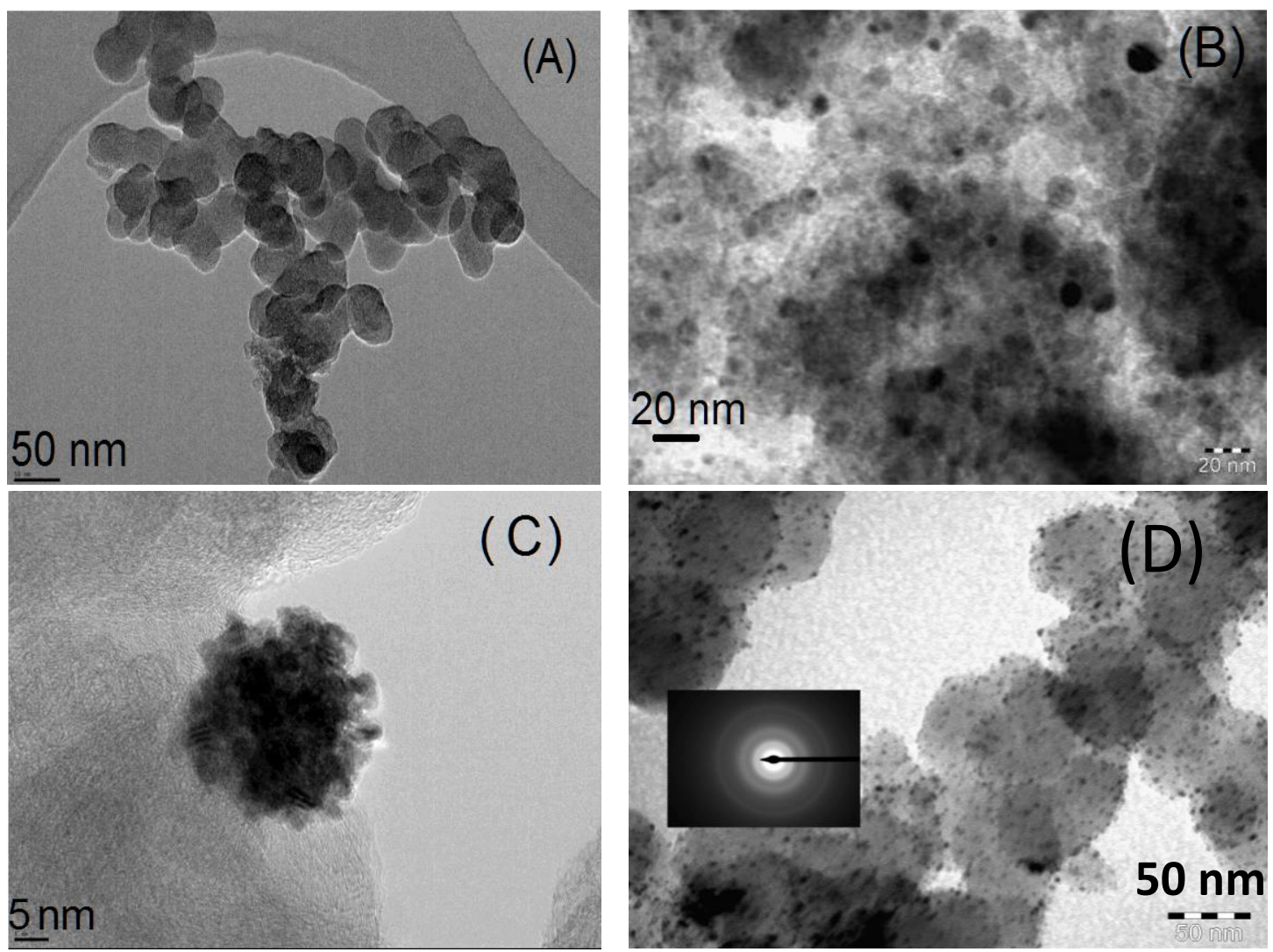

Figure 5. TEM micrographs of Pt(Cu) particles supported on carbon particles (Pt(Cu)/C) (see Experimental); (A), (B), (C) Micrographs at different magnifications as indicated by the scale bars.

For comparison, a micrograph for commercial $20 \% \mathrm{w} / \mathrm{w}$ Pt/C catalyst (ETEK) is shown in (D)

\section{b. Electrochemical characterisation of $\mathrm{Pt}(\mathrm{Cu}) / \mathrm{C}$ in acid}

Figure 6 presents the stabilized picture (see Experimental) of cyclic voltammograms of the $\mathrm{Pt}(\mathrm{Cu}) / \mathrm{C}$ and $\mathrm{Pt} / \mathrm{C}$ electrodes, obtained at $50 \mathrm{mVs}^{-1}$ in acid. Both electrodes show the typical hydrogen adsorption/desorption and oxide formation/stripping features of high surface areacarbon-supported Pt. This is macroscopic evidence that the outer surface of the $\mathrm{Pt}(\mathrm{Cu})$ catalyst is made of a pure, protective Pt shell.

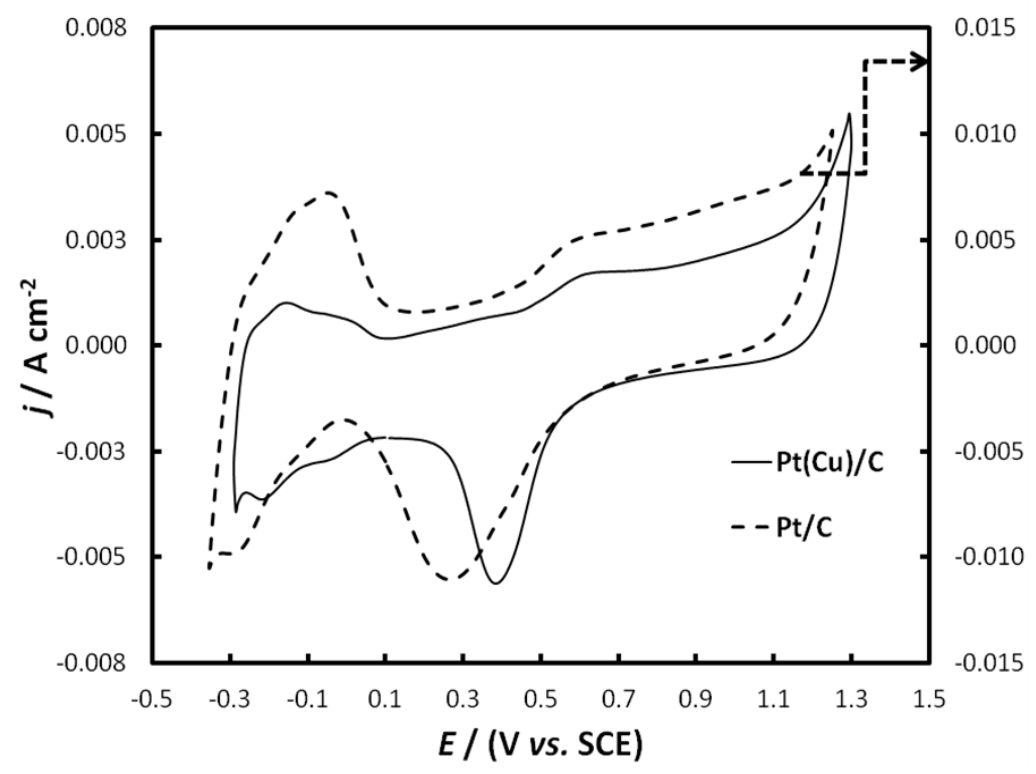

Figure 6. Cyclic voltammograms ( $50 \mathrm{mV} \mathrm{s}^{-1}$ potential scan rate) of Pt(Cu)/C and Pt/C electrodes in deaerated $0.1 \mathrm{M} \mathrm{HClO}_{4}$ 
Two further points can be made: first, the hydrogen peak area (between +0.1 and $-0.3 \mathrm{~V}$ ) is smaller for the $\mathrm{Pt}(\mathrm{Cu})$ electrode, as expected for a low specific area due to larger particles and aggregation phenomena (Figure 5); second, the ill-defined hydrogen peak area (typical of carbonsupported Pt nanoparticles) does not allow for a reliable estimate of the catalyst electroactive area (from the charge corresponding to the area under the cathodic or anodic part of the curve in that range, associated with adsorption and desorption of a $\mathrm{H}$ monolayer).

In order to obtain a more accurate estimate of the catalyst electroactive area we therefore resort to the oxidative removal of a pre-adsorbed $\mathrm{CO}$ monolayer during the positive-going potential scan of the voltammograms shown in Figure 7 (see also Experimental). The anodic charge between ca +0.4 and $+0.7 \mathrm{~V}$ corresponds to the oxidation of a full CO monolayer and is associated with a charge density of $420 \mu \mathrm{C} \mathrm{cm}^{-2}$ of Pt [53]. The Pt electroactive area (per electrode substrate geometric area) of the catalyst layers can thus been calculated as $5.19 \mathrm{~cm}^{2} \mathrm{~cm}^{-2}$ for $\mathrm{Pt}(\mathrm{Cu}) / \mathrm{C}$ and $77.92 \mathrm{~cm}^{2} \mathrm{~cm}^{-2}$ for Pt/C. The mass specific electroactive areas in the prepared coatings can then be estimated (based on the Pt loadings-see Experimental) as 2.6 and $18.1 \mathrm{~m}^{2} \mathrm{~g}^{-1}$ respectively. (Such low values can be interpreted by extensive agglomeration taking place in coatings with relatively large catalyst loadings; note that ca $1 \mathrm{mg}$ of catalyst and support were loaded over a $0.385 \mathrm{~cm}^{2}$ surface, resulting in a ca $2.5 \mathrm{mg} \mathrm{cm}^{-2}$ of catalyst+support total loading).

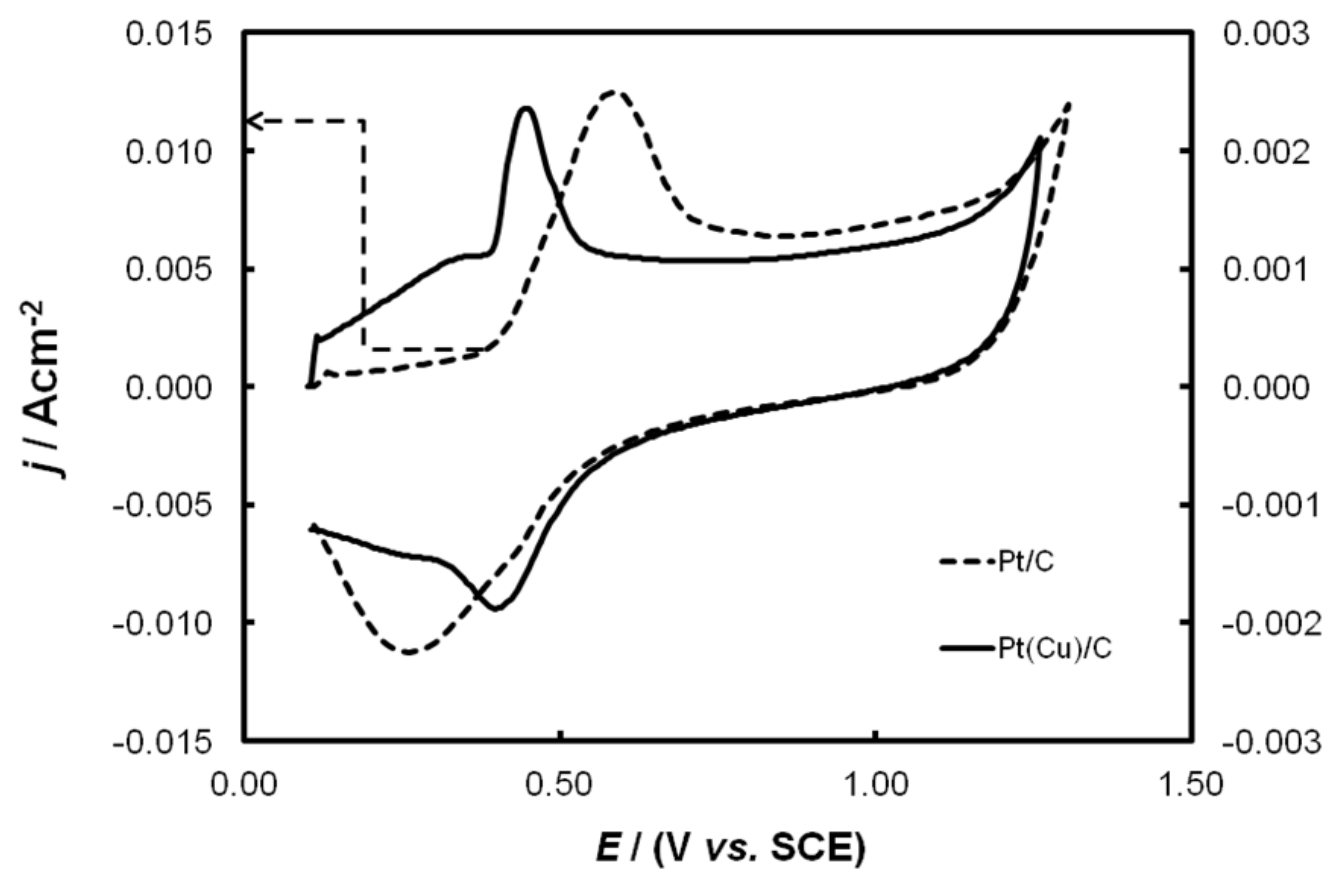

Figure 7. Cyclic voltammograms (50 mV s-1 potential scan rate) of Pt(Cu)/C and Pt/C electrodes in a deaerated $0.1 \mathrm{M} \mathrm{HClO}_{4}$, following $\mathrm{CO}$ pre-adsorption from a $\mathrm{CO}$-saturated solution

The most interesting feature of the voltammograms of Figure 7 is the ca $150 \mathrm{mV}$ negative shift of the $\mathrm{CO}$ oxidation peak in the case of the $\mathrm{Pt}(\mathrm{Cu})$ catalyst, proving its better catalytic activity for $\mathrm{CO}$ oxidation. Note that this is higher than the shift obtained at other $\mathrm{Pt}(\mathrm{Cu})$ systems prepared by galvanic replacement where $\mathrm{C}$ was present during the replacement step (and thus some of Pt was deposited directly on $\mathrm{C}$ and remained without strong Pt-Cu interactions) $[29,30]$.

Figure 8 presents the positive-going voltammogram corresponding to methanol oxidation, with the current density, $j_{e}$, reported per Pt electroactive surface area as obtained from the results of Figure 7. It can be seen that the intrinsic activity (corrected for mere surface area effects) of the $\mathrm{Pt}(\mathrm{Cu})$ catalyst is superior to that of plain Pt catalysts, highlighting the beneficial effect of Pt-Cu 
interactions on methanol oxidation, presumably because of its ability to remove the CO poisonous intermediate, in line with the findings of the oxidative CO removal discussed above. The current density obtained is the highest among similar catalysts $[29,30]$.

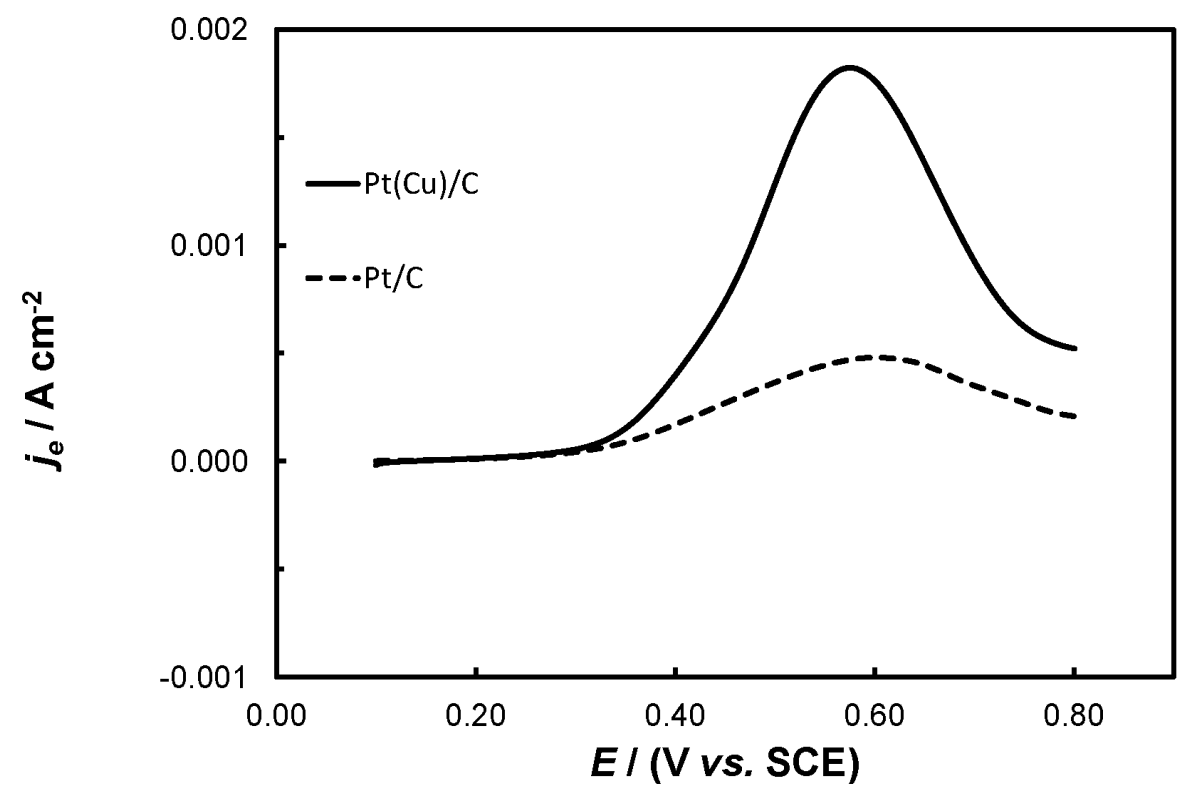

Figure 8. Voltammograms (5 $\mathrm{mV} \mathrm{s}^{-1}$ potential scan rate; positive going scan) of $\mathrm{Pt}(\mathrm{Cu}) / \mathrm{C}$ and $\mathrm{Pt} / \mathrm{C}$ electrodes in $0.5 \mathrm{M} \mathrm{MeOH}+0.1 \mathrm{M} \mathrm{HClO}_{4}$ solutions; current densities, $\mathrm{j}_{e}$ are per electroactive surface area

In Figure 9 the positive-going voltammograms for methanol oxidation are shown again, where the current density, $j_{\mathrm{m}}$, is now reported per mass of Pt. In this case, the commercial catalyst appears to be better since the effect of very low surface area of $\mathrm{Pt}(\mathrm{Cu})$ (see large particles and agglomerates in Figure 5) overrides its higher intrinsic catalytic activity.

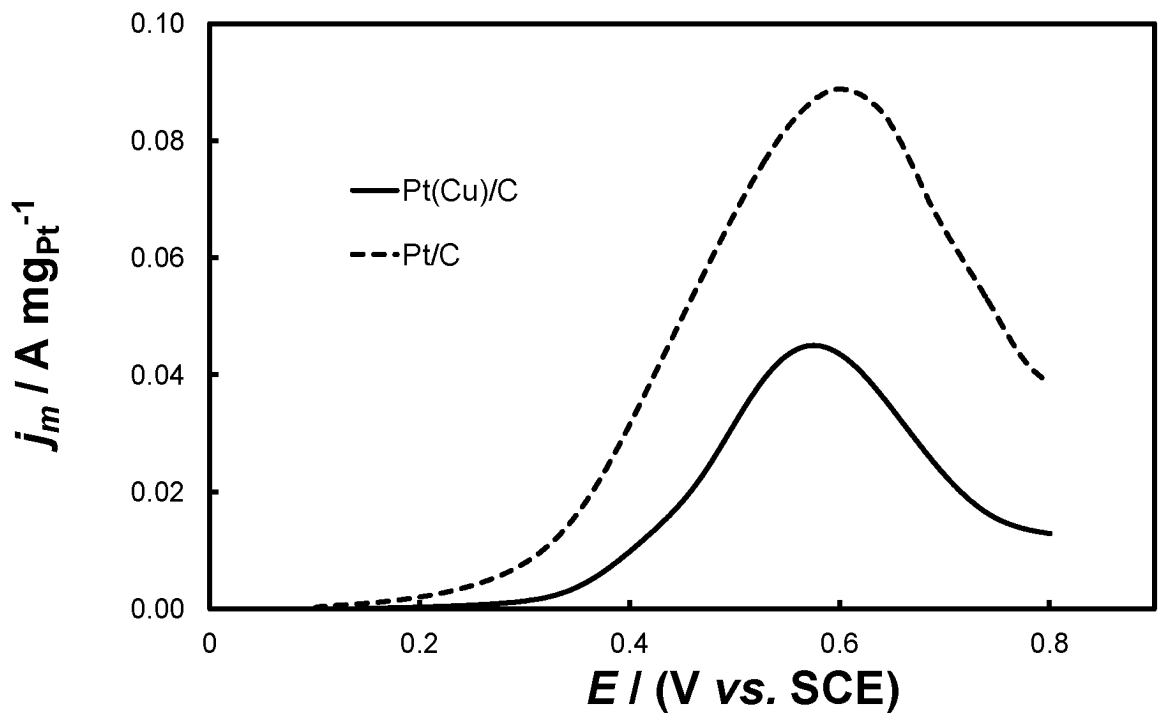

Figure 9. Voltammograms ( $5 \mathrm{mV} \mathrm{s}^{-1}$ potential scan rate; positive going scan) of $\mathrm{Pt}(\mathrm{Cu}) / \mathrm{C}$ and $\mathrm{Pt} / \mathrm{C}$ electrodes in $0.5 \mathrm{M} \mathrm{MeOH}+0.1 \mathrm{M} \mathrm{HClO}_{4}$ solutions; current densities, $\mathrm{j}_{m}$, are per mass of $\mathrm{Pt}$

\section{Conclusions}

i. Bimetallic Pt-Cu catalysts have been prepared by partial galvanic replacement of $\mathrm{Cu}$ nanoparticles synthesized by a precipitation/reduction method. The catalyst was then supported on a high surface area $\mathrm{C}$ powder. 
ii. Following electrochemical treatment in acid the voltammetric picture of the $\mathrm{Pt}(\mathrm{Cu}) / \mathrm{C}$ electrode was similar to that of a pure $\mathrm{Pt} / \mathrm{C}$ one, indicating the formation of a protective outer $\mathrm{Pt}$ shell over a Cu-containing core ( $\mathrm{Pt}(\mathrm{Cu}))$.

iii. The $\mathrm{Pt}(\mathrm{Cu}) / \mathrm{C}$ electrodes have superior intrinsic catalytic activity towards $\mathrm{CO}$ oxidation and methanol oxidation in acid.

iv. Due to the formation of large $\mathrm{Pt}(\mathrm{Cu})$ particles and extensive agglomeration, the bimetallic catalyst exhibited a low electroactive surface area and hence a moderate mass specific activity.

$v$. Future research should be directed towards the preparation of smaller $\mathrm{Pt}(\mathrm{Cu})$ bimetallic nanoparticles (possibly by the synthesis of smaller $\mathrm{Cu}$ particle precursors) so that not only the intrinsic catalytic activity is improved (due to Pt-Cu interactions) but also the overall, mass specific activity increases significantly (due to a higher surface area).

Acknowledgements: This research has been co-financed by the European Union (European Social Fund - ESF) and Greek national funds through the Operational Program "Education and Lifelong Learning" of the National Strategic Reference Framework (NSRF) - Research Funding Program: Heracleitus II. Investing in knowledge society through the European Social Fund.

\section{References}

[1] E. Antolini, Appl. Catal. B: Env. 74 (2007) 324

[2] E. Antolini, J. Mater. Sci. 38 (14) (2003) 2995

[3] C. R. K. Rao, D. C. Trivedi, Coordination Chem. Rev. 249 (2005) 613

[4] H. Bonnemann, W. Brixoux, R. Brinkmann, E. Dinjus, T. Jouben, B. Korall, Angew. Chem. Int. Ed. Engl. 30 (1991) 1312

[5] M. Boutonnet, J. Kizling, P. Stenius, G. Maire, Colloids Surf. 5 (1982) 209

[6] G. Kokkinidis, A. Papoutsis, D. Stoychev, A. Milchev, J. Electroanal. Chem. 486 (2000) 48

[7] G. Kokkinidis, D. Stoychev, V. Lazarov, A. Papoutsis, A. Milchev, J. Electroanal. Chem. 511 (2001) 20

[8] S. R. Brankovic, J. X. Wang, R. R. Adzic, Surf. Sci. 474 (2001) L173

[9] S. R. Brankovic, J. McBreen, R. R. Adzic, J. Electroanal. Chem. 503 (2001) 99

[10] S. R. Brankovic, J. McBreen, R.R. Adzic, Surf. Sci. 479 (2001) L363

[11] M. Van Brussel, G. Kokkinidis, I. Vandendael, C. Buess-Herman, Electrochem. Commun. 4 (10) (2002) 808

[12] M. Van Brussel, G. Kokkinidis, A. Hubin, Cl. Buess-Herman, Electrochim. Acta 48 (2003) 3909

[13] K. Sasaki, Y. Mo, J. X. Wang, M. Balasubramanian, F. Uribe, J. McBreen, R. R. Adzic, Electrochim. Acta 48 (25-26) (2003) 3841

[14] K. Sasaki, J. X. Wang, M. Balasubramanian, J. McBreen, F. Uribe, R. R. Adzic, Electrochim. Acta 49 (22-23) (2004) 3873

[15] J. Zhang, M. B. Vukmirovic, K. Sasaki, A. U. Nilekar, M. Mavrikakis, R. R. Adzic, J. Am. Chem. Soc. 127 (36) (2005) 12480

[16] J. Zhang, F. H. Lima, M. H. Shao, K. Sasaki, J. X. Wang, J. Hanson, R. R. Adzic, J. Phys. Chem. B 109(48) (2005) 22701

[17] R. R. Adzic, J. Zhang, K. Sasaki, M. B.Vukmirovic, M. Shao, J. X.Wang, A. U. Nilekar, M. Mavrikakis, J. A. Valerio, F. Uribe, Top. Catal. 46 (2007) 249

[18] Y. Ando, K. Sakaki, R. Adzic, Electrochem.Commun. 11 (2009) 1135

[19] K. Sasaki, H. Naohara, Y. Cai, Y. M. Choi, P. Liu, M. B. Vukmirovic, J. X. Wang, R.R. Adzic, Ang. Chem. Int. Ed. 49 (46) (2010) 8602 
[20] S. Papadimitriou, A. Tegou, E. Pavlidou, G. Kokkinidis, S. Sotiropoulos, Electrochim. Acta 52 (2007) 6254

[21] A. Tegou, S. Papadimitriou, E. Pavlidou, G. Kokkinidis, S. Sotiropoulos, J. Electroanal. Chem. 608 (2007) 67

[22] S. Papadimitriou, A. Tegou, E. Pavlidou, G. Kokkinidis, S. Sotiropoulos, Electrochim. Acta 53 (2008) 6559

[23] A. Tegou, S. Papadimitriou, S. Armyanov, E. Valova, G. Kokkinidis, S. Sotiropoulos, J. Electroanal. Chem. 623 (2) (2008) 187

[24] A.Tegou, S.Armyanov, E.Valova, O.Steenhaut, A. Hubin, G. Kokkinidis, S. Sotiropoulos, J. Electronal. Chem. 634 (2) (2009) 104

[25] A. Tegou, S. Papadimitriou, G. Kokkinidis, S. Sotiropoulos, J. Solid State Electrochem. 14 (2) (2010) 175

[26] S. Papadimitriou, S. Armyanov, E. Valova, A. Hubin, O. Steenhaut, E. Pavlidou, G. Kokkinidis, S. Sotiropoulos, J. Phys. Chem. C 114 (11) (2010) 5217

[27] A. Tegou, S. Papadimitriou, I. Mintsouli, S. Armyanov, E. Valova, G. Kokkinidis, S. Sotiropoulos, Catalysis Today 170 (1) (2011) 126

[28] I. Mintsouli, J. Georgieva, E. Valova, S. Armyanov, A. Kakaroglou, A. Hubin, O. Steenhaut, J. Dille, A. Papaderakis, G. Kokkinidis, S. Sotiropoulos, J. Solid State Electrochem. 17 (2) (2013) 435

[29] I. Mintsouli, J. Georgieva, S. Armyanov, E. Valova, G. Avdeev, A. Hubin, O. Steenhaut, J. Dille, D. Tsiplakides, S. Balomenou, S. Sotiropoulos, Appl. Catal. B: Env. 136-137 (2013) 160

[30] J. Georgieva, E. Valova, I. Mintsouli, S. Sotiropoulos, S. Armyanov, A. Kakaroglou, A. Hubin, O. Steenhaut, J. Dille, J. Appl. Electrochem. 44 (2) (2014) 215

[31] B. Geboes, I. Mintsouli, B. Wouters, J. Georgieva, A. Kakaroglou, S. Sotiropoulos, E. Valova, S. Armyanov, A. Hubin, T. Breugelmans, Appl. Catal. B: Env. 150-151 (2014) 249

[32] J. Georgieva, S. Sotiropoulos, E. Valova, S. Armyanov, N. Karanasios, J. Electroanal. Chem. 727 (2014) 135

[33] J. Georgieva, E. Valova, I. Mintsouli, S. Sotiropoulos, D. Tatchev, S. Armyanov, A. Hubin, J. Dille, A. Hoell, V. Raghuwanshi, N. Karanasios, L. Malet, J. Electroanal. Chem. 754 (2015) 65

[34] B. I. Podlovchenko, T. D. Gladysheva, A. Y. Filatov, L. V. Yashina, Russ. J. Electrochem. 46 (10) (2010) 1189

[35] V. V. Kuznetsov, B. I. Podlovchenko, K. V. Kavyrshina, Yu M. Maksimov, Russ. J. Electrochem. 46 (12) (2010) 1353

[36] B. I. Podlovchenko, U. E. Zhumaev, Y. M. Maksimov, J. Electroanal. Chem. 651 (1) (2011) 30

[37] B. I. Podlovchenko, V. A. Krivchenko, Yu M. Maksimov, T. D. Gladysheva, L. V. Yashina, S. A. Evlashin, A. A. Pilevsky, Electrochim. Acta 76 (2012) 137

[38] B. I. Podlovchenko, Y. M. Maksimov, K. I. Maslakov, Electrochim. Acta 130 (2014) 351

[39] B. I. Podlovchenko, Y. M. Maksimov, S. A. Evlashin, T. D. Gladysheva, K. I. Maslakov, V. A. Krivchenko, J. Electroanal. Chem. 743 (2015) 93

[40] C. Lamy, J. -M. Léger, S. Srinivasan, in J. O. M. Bockris, B. E. Conway (Eds.), Modern Aspects of Electrochemistry, Vol.34, Plenum Press, NY, 2000, Ch.3, p. 53

[41] A. Hamnett, in W. Vielstich, A. Lamm, H. A. Gasteiger (Eds.), Handbook of Fuel Cells: Fundamentals Technology and Applications, Wiley, Chichester, 2003, Vol.1, Ch.18, p. 305

[42] B. Beden, F. Kadirgan, C. Lamy, J. -M. Léger, J. Electroanal. Chem. 127 (1981) 75

[43] H. Zhao, L. Li, J. Yang, Y. Zhang, Electrochem. Commun. 10 (2008) 1527

[44] M. K. Jeon, J. S. Cooper, P. J. McGinn, J. Power Sources 185 (2008) 913

[45] Y. J. Kuang, B. H. Wu, Y. Cui, Y. M. Yu, X. H. Zhang, J. H. Chen, Electrochim. Acta 56 (2011) 8645

[46] X. Yu, D. Wang, Q. Peng, Y. Li, Chem.Commun. 47 (2011) 8094 
[47] A. Sarkar, A. Manthiram, J. Phys. Chem. C 114 (2010) 4725

[48] C. Du, M. Chen, W. Wang, Q. Tan, K. Xiong, C. Yin, J. Power Sources 240 (2013) 630

[49] Q. Li, P. Xu, B. Zhang, G. Wu, H. Zhao, E. Fu, H. Wang, Nanoscale 5 (16) (2013) 7397

[50] J. M. Sieben, A. E. Alvarez, V. Comignani, M. M. E. Duarte, Int. J. Hydrogen Energy 39 (22) (2014) 11547

[51] J. M. Sieben, A. E. Alvarez, V. Comignani, M. M. E. Duarte, Int. J. Hydrogen Energy 39 (16) (2014) 8667

[52] Y. -X. Wang, H. -J. Zhou, P. -C. Sun, T. -H. Chen, J. Power Sources 245 (2014) 663

[53] R. W. Lindström, K. Kortsdottir, M. Wesselmark, A. Oyarce, C. Lagergren, G. Lindbergh, J. Electrochem. Soc. 157 (12) (2010) B1795

(C) 2016 by the authors; licensee IAPC, Zagreb, Croatia. This article is an open-access article distributed under the terms and conditions of the Creative Commons Attribution license (http://creativecommons.org/licenses/by/4.0/) (cc) EY 